\begin{tabular}{|l|l|l||}
\hline \multicolumn{2}{|c|}{ PublisherInfo } \\
\hline \hline PublisherName & $:$ & BioMed Central \\
\hline \hline PublisherLocation & $:$ & London \\
\hline \hline PublisherImprintName & $:$ & BioMed Central \\
\hline \hline
\end{tabular}

\title{
Web site featuring complete books
}

\begin{tabular}{|l|l|l||}
\hline \multicolumn{2}{|c|}{ ArticleInfo } \\
\hline \hline ArticleID & $:$ & 4227 \\
\hline \hline ArticleDOI & $:$ & $10.1186 /$ ccf-1999-webreport102 \\
\hline \hline ArticleCitationID & $:$ & webreport102 \\
\hline \hline ArticleSequenceNumber & $:$ & 15 \\
\hline \hline ArticleCategory & $:$ & Web report \\
\hline \hline ArticleFirstPage & $:$ & 1 \\
\hline \hline ArticleLastPage & $:$ & 3 \\
\hline \hline & & RegistrationDate : 1999-12-6 \\
\hline ArticleHistory & $:$ & OnlineDate \\
\hline \hline ArticleCopyright & $:$ & Current Science Ltd1999-12-6 \\
\hline \hline ArticleGrants & $:$ & \\
\hline \hline ArticleContext & $:$ & 1305433 \\
\hline \hline
\end{tabular}




\section{Overview}

Hoping for some teaching ideas, I recently purchased the 2nd edition (1999) of 'All You Really Need to Know to Interpret Arterial Blood Gases' by Lawrence Martin, MD. In it I found the URL for this website produced by the author who is Chief of the Division of Pulmonary and Critical Care Medicine at Mt Sinai. It has a variety of items, but most interestingly, several books are published here by the same author. There are parts of 'All You Really Need to Know...'; there is an entire book on physiological and medical aspects of scuba diving; and there is a complete book covering casual critical care reading of case reports/discussions - "'We Can't Kill Your Mother!" and Other Stories of Intensive Care'.

\section{Content}

This is a site with a variety of items of interest to the critical care community. There is no new information, but there are some clear, simple presentations of common problems, such as how to diagnose mixed acid-base disorder or a brief discussion of air embolus in scuba diving. There are casual presentations of critical care cases, that will be of interest just to see how another critical care colleague thinks.

\section{Other comments}

Cannot say for sure, but there is a 'Feature of the Month' page.

\section{Evaluation}

No special access requirements. 


\section{References}

1. Mt Sinai Medical Center (Cleveland) - Division of Pulmonary and Critical Care Medicine. [http://www.mtsinai.org/pulmonary/]

This PDF file was created after publication. 